\title{
ANALISIS PRODUK DOMESTIK REGIONAL BRUTO (PDRB) DAN PERTUMBUHAN EKONOMI KABUPATEN SUBANG TAHUN 2017/2018
}

\author{
${ }^{1}$ Cahyono, ${ }^{2}$ Saiful Almujab, ${ }^{3} \mathrm{~S}$ Marten Yogaswara \\ 1,2,3 Universitas Pasundan \\ Email: cahyono@unpas.co.id
}

\begin{abstract}
Development and economic growth of a region can be seen through the instruments of Gross Domestic Product (GDP) or Gross Regional Domestic Product (GDP). Gross Regional Domestic Product according to expenditure (Expenditure GRDP) is one form of displaying economic data of a region, other display forms such as GRDP according to business fields, Input-Output Tables, Socio-Economic Balance System, and Funds Flow Balance. The method of writing this article uses a literature study, using secondary data as the main data source. The economy of Subang Regency for the period 2013 - 2018 can grow above 4\%. In terms of production, the highest economic growth occurred in the Information and Communication category which grew above 6\% annually. In terms of final demand, the economic growth of Subang Regency is dominated by growth in the component of Household Consumption Expenditures (PK-RT), which accounts for more than half of the total regency sub-district GDP.
\end{abstract}

Keywords: Economic Growth, Expenditure GRDP, and Business Field GRDP

\begin{abstract}
ABSTRAK
Pembangunan dan pertumbuhan ekonomi suatu wilayah dapat dilihat melalui intrumen Produk Domestik Bruto (PDB) atau Produk Domestik Regional Bruto (PDRB). Produk Domestik Regional Bruto menurut pengeluaran (PDRB Pengeluaran) merupakan salah satu bentuk tampilan data ekonomi suatu wilayah, bentuk tampilan lain seperti PDRB menurut lapangan usaha, Tabel InputOutput, Sistem Neraca Sosial Ekonomi, dan Neraca Arus Dana. Metode penulisan artikel ini dengan menggunakan studi pusta, dengan menggunakan data sekunder sebagai sumber data utama. Perekonomian Kabupaten Subang periode 2013 - 2018 dapat tumbuh di atas 4\%. Dari sisi produksi, pertumbuhan ekonomi tertinggi terjadi pada kategori Informasi dan Komunikasi yang tumbuh di atas 6\% setiap tahunnya. Dari sisi permintaan akhir, pertumbuhan ekonomi Kabupaten Subang didominasi pertumbuhan komponen Pengeluaran Konsumsi Rumahtangga (PK-RT), yang menyumbang lebih dari separuh total PDRB kabupaten subang.
\end{abstract}

Kata Kunci: Pertumbuhan Ekonomi, PDRB Pengeluaran, dan PDRB Lapangan Usaha

\section{PENDAHULUAN}

Pertumbuhan ekonomi merupakan salah satu indikator untuk melihat hasil pembangunan yang telah dilakukan dan juga berguna untuk menentukan arah pembangunan di masa yang akan datang. Pertumbuhan ekonomi yang positif menunjukkan adanya peningkatan perekonomian, sebaliknya pertumbuhan ekonomi negatif menunjukkan adanya penurunan dalam perekonomian (Putra \& Windhu, 2017). Pertumbuhan ekonomi menjadi tujuan bangsa agar dapat pula meningkatkan pembangunan nasional yang dapat meningkatkan kualitas manusia dan masyarakat Indonesia yang dilakukan secara berkelanjutan berdasarkan kemampuan nasional. 
Menurut Todaro dan Smith (2006) pertumbuhan ekonomi merupakan suatu proses peningkatan kapasitas produktif dalam suatu perekonomian secara terus menerus atau berkesinambungan sepanjang waktu sehingga menghasilkan tingkat pendapatan dan output nasional yang semakin lama semakin besar. Tiga komponen pertumbuhan ekonomi yang penting bagi setiap masyarakat adalah (1) Akumulasi modal, termasuk di dalamnya semua investasi baru dalam bentuk tanah, peralatan fisik dan sumber daya manusia melalui perbaikan di bidang kesehatan, pendidikan dan keterampilan kerja, (2) Pertumbuhan jumlah penduduk yang pada akhirnya menyebabkan petumbuhan angkatan kerja, (3) Kemajuan teknologi yang secara luas diartikan sebagai cara baru dalam menyelesaikan pekerjaan (Anitasari \& Soleh, 2012a). Pertumbuhan ekonomi yang tinggi dan prosesnya yang berkelanjutan merupakan kondisi utama bagi kelangsungan pembangunan ekonomi.

Pembangunan dan pertumbuhan ekonomi suatu wilayah dapat dilihat melalui intrumen Produk Domestik Bruto (PDB) atau Produk Domestik Regional Bruto (PDRB). Produk Domestik Regional Bruto (PDRB) merupakan salah satu perangkat data ekonomi yang dapat digunakan untuk mengevaluasi kinerja pembangunan ekonomi suatu wilayah (provinsi maupun kabupaten/kota) (BPS. Kab. Subang, 2018). Perangkat data ini dapat pula digunakan untuk kepentingan dan tujuan lain, seperti sebagai dasar pengembangan model-model ekonomi dalam rangka menyusun formulasi kebijakan, tingkat percepatan uang beredar (velocity of money), pendalaman sektor keuangan (finacial deepening), penetapan pajak, kajian ekspor dan impor dan sebagainya.

Produk Domestik Regional Bruto menurut pengeluaran (PDRB Pengeluaran) merupakan salah satu bentuk tampilan data ekonomi suatu wilayah. Di dalam sistem kerangka kerja (frame work) data ekonomi suatu wilayah, PDRB Pengeluaran merupakan ukuran dasar (basic measure) yang menggambarkan penggunaan atas barang dan jasa (product) yang dihasilkan melalui aktivitas produksi. Dalam konteks ini, PDRB Pengeluaran itu menggambarkan hasil akhir dari proses batas-batas teritori suatu wilayah. Berbagai jenis barang dan jasa akhir tersebut akan digunakan untuk memenuhi permintaan akhir oleh pelaku ekonomi domestik maupun pelaku ekonomi dari luar wilayah bahkan dari luar negeri. Beberapa agregat penting dapat diturunkan dari PDRB Pengeluaran ini seperti variabel Pengeluaran Konsumsi Akhir, pembentukan modal tetap bruto atau investasi fisik, serta ekspor dan impor. (BPS. Kab. Subang, 2018)

\section{LANDASAN TEOR}

Produk Domestik Regional Bruto menurut pengeluaran (PDRB Pengeluaran) merupakan salah satu bentuk tampilan data ekonomi suatu wilayah, di samping bentuk tampilan lain seperti PDRB menurut lapangan usaha, Tabel Input-Output, Sistem Neraca Sosial Ekonomi, dan Neraca Arus Dana (BPS. Kab. Subang, 2018). Di dalam sistem kerangka kerja (frame work) data ekonomi suatu wilayah, PDRB Pengeluaran merupakan ukuran dasar (basic measure) yang menggambarkan penggunaan atas barang dan jasa (product) yang dihasilkan melalui aktivitas produksi. Dalam konteks ini dapat dipahami bahwa, PDRB Pengeluaran itu menggambarkan hasil akhir dari proses produksi yang berlangsung dalam batas-batas teritori suatu wilayah. Berbagai jenis barang dan jasa akhir tersebut akan digunakan untuk memenuhi permintaan akhir oleh pelaku ekonomi domestik maupun pelaku ekonomi dari luar wilayah bahkan dari luar negeri. Beberapa agregat penting dapat diturunkan dari PDRB Pengeluaran ini seperti variabel Pengeluaran Konsumsi Akhir, pembentukan modal tetap bruto atau investasi fisik, serta ekspor dan impor (BPS. Kab. Subang, 2018).

Melalui PDRB Pengeluaran juga dapat dilihat keterkaitannya dengan penyediaan barang dan jasa yang berasal dari domestik maupun dari impor. Melalui hubungan ini terlihat titik keseimbangan makro antara sisi penyediaan (supply side) dan sisi permintaan (demand side) barang dan jasa. 
Dengan demikian PDRB Pengeluaran menjelaskan besarnya nilai barang dan jasa (output) yang dihasilkan dalam wilayah domestik, yang digunakan sebagai konsumsi akhir oleh masyarakat. Secara spesifik, yang dimaksud dengan konsumsi akhir adalah penggunaan barang dan jasa yang tidak dimaksukan untuk diproses lebih lanjut (dikonsumsi habis). Penggunaan produk akhir tersebut diwujudkan dalam bentuk permintaan akhir (BPS. Kab. Subang, 2018). Adapun yang dimaksud dari permintaan akhir tersebut dapat dirinci sebagai berikut:

1. Pengeluaran Konsumsi Akhir Rumahtangga (PK-RT),

2. Pengeluaran Konsumsi Akhir Lembaga Non Profit Yang Melayani Rumahtangga (PKLNPRT),

3. Pengeluaran Konsumsi Akhir Pemerintah (PK-P),

4. Pembentukan Modal Tetap Bruto (PMTB),

5. Perubahan Inventori (PI), serta

6. Komponen Ekspor Barang dan Jasa.

Pertumbuhan ekonomi merupakan dampak dari adanya peningkatan PDRB dari suatu wilayah. Kita tau bahwa Pertumbuhan ekonomi adalah proses perubahan kondisi perekonomian suatu negara secara berkesinambungan menuju keadaan yang lebih baik selama periode tertentu. Pertumbuhan ekonomi dapat diartikan juga sebagai proses kenaikan kapasitas produksi suatu perekonomian yang diwujudkan dalam bentuk kenaikan pendapatan nasional. Adanya pertumbuhan ekonomi merupakan indikasi keberhasilan pembangunan ekonomi dalam kehidupan masyarakat.

Pertumbuhan ekonomi suatu wilayah atau negara dapat diukur dengan cara membandingkan, misalnya untuk ukuran nasional, Gross National Product (GNP) / GDRB, tahun yang sedang berjalan dengan tahun sebelumnya. Faktor-faktor yang mempengaruhi pertumbuhan ekonomi sebagaimana dijelaskan dalam https://id.wikipedia.org/wiki/ Pertumbuhan_ekonomi adalah sebagai berikut:

1. Faktor Sumber Daya Manusia

Sama halnya dengan proses pembangunan, pertumbuhan ekonomi juga dipengaruhi oleh SDM. Sumber daya manusia merupakan faktor terpenting dalam proses pembangunan, cepat lambatnya proses pembangunan tergantung kepada sejauh mana sumber daya manusianya selaku subjek pembangunan memiliki kompetensi yang memadai untuk melaksanakan proses pembangunan dengan membangun infrastruktur di daerah-daerah.

2. Faktor Sumber Daya Alam

Sebagian besar negara berkembang bertumpu kepada sumber daya alam dalam melaksanakan proses pembangunannya. Namun, sumber daya alam saja tidak menjamin keberhasilan proses pembanguan ekonomi, apabila tidak didukung oleh kemampaun sumber daya manusianya dalam mengelola sumber daya alam yang tersedia. Sumber daya alam yang dimaksud dinataranya kesuburan tanah, kekayaan mineral, tambang, kekayaan hasil hutan dan kekayaan laut.

3. Faktor Ilmu Pengetahuan dan Teknologi

Perkembangan ilmu pengetahuan dan teknologi yang semakin pesat mendorong adanya percepatan proses pembangunan, pergantian pola kerja yang semula menggunakan tangan manusia digantikan oleh mesin-mesin canggih berdampak kepada aspek efisiensi, kualitas dan kuantitas serangkaian aktivitas pembangunan ekonomi yang dilakukan dan pada akhirnya berakibat pada percepatan laju pertumbuhan perekonomian.

4. Faktor Budaya

Faktor budaya memberikan dampak tersendiri terhadap pembangunan ekonomi yang dilakukan, faktor ini dapat berfungsi sebagai pembangkit atau pendorong proses pembangunan tetapi dapat juga menjadi penghambat pembangunan. Budaya yang dapat mendorong pembangunan diantaranya sikap kerja keras dan kerja cerdas, jujur, ulet dan 
sebagainya. Adapun budaya yang dapat menghambat proses pembangunan diantaranya sikap anarkis, egois, boros, KKN (Korupsi, Kolusi dan Nepotisme), dan sebagainya.

5. Sumber Daya Modal

Sumber daya modal dibutuhkan manusia untuk mengolah SDA dan meningkatkan kualitas IPTEK. Sumber daya modal berupa barang-barang modal sangat penting bagi perkembangan dan kelancaran pembangunan ekonomi karena barang-barang modal juga dapat meningkatkan produktivitas

\section{METODOLOGI}

Metode pengumpulan data yang digunakan dalam penulisan artikel ini adalah metode studi kepustakaan. Metode ini merupakan cara pengumpulan data dengan mengadakan pengkajian kepustakaan yaitu dengan mempelajari bahan-bahan bacaan yang berhubungan dengan penelitian ini, seperti Badan Pusat Statistik (BPS), perpustakan, jurnal dan buku-buku lainnya.

Data yang digunakan dalam penelitian ini adalah data sekunder. Data sekunder merupakan data yang telah tersedia dan telah diproses oleh pihak-pihak lain sebagai hasil atas penelitian yang telah dilaksanakan. Sumber data tersebut antara lain:

1. Badan Pusat Statistik (BPS) Kabupaten Subang

2. Pusdalisbang Jawa Barat

3. BAPPEDA dan Dinas - dinas lainya.

(BPS. Kab. Subang, 2018)

\section{HASIL DAN PEMBAHASAN}

Terbentuknya total Produk Domestik Regional Bruto (PDRB) pengeluaran tidak trelepas dari kontribusi seluruh komponen, yang terdiri dari komponen Pengeluaran Konsumsi, Akhir Rumahtangga (PK-RT), Pengeluaran Konsumsi Akhir Lembaga Non Profit Yang Melayani Rumah Tangga (PK-LNPRT), Pengeluaran Konsumsi Akhir Pemerintah (PK-P), Pembentukan Modal Tetap Bruto (PMTB), ekspor neto (E) atau ekspor minus impor barang dan jasa. (Predisetian, 2017)

Penyusunan PDRB dengan tahun dasar baru juga disertai dengan upaya untuk mengimplementasikan System of National Accounts (SNA) yang baru, SNA 2008. Ke dua hal tersebut tentu berdampak pada besaran maupun struktur PDRB serta indikator ekonomi yang diturunkan dari data PDB/PDRB tersebut.

Salah satu indikator pembangunan yang dapat digunakan untuk menilai kemajuan ekonomi secara makro suatu wilayah adalah dengan pendekatan Produk Domestik Regional Bruto (PDRB). Produk Domestik Regional Bruto (PDRB) merupakan salah satu data statistik yang digunakan dalam sistem evaluasi dan perencanaan ekonomi makro suatu wilayah.

Perkembangan Produk Domestik Regional Bruto (PDRB) Kabupaten Subang menggambarkan pertumbuhan ekonomi dari tahun ke tahun, sehingga arah perekonomian daerah akan lebih jelas. PDRB juga merupakan indikator untuk mengatur sampai sejauh mana keberhasilan pemerintah dalam memanfaatkan sumber daya yang ada dan dapat digunakan sebagai perencanaan dan pengambilan keputusan yang salah satunya untuk meningkatkan potensi yang ada. PDRB adalah nilai bersih barang dan jasa-jasa akhir yang dihasilkan oleh berbagai kegiatan ekonomi di suatu daerah dalam periode (Kuncoro, 2006). PDRB dapat menggambarkan kemampuan suatu daerah mengelola sumber saya alam yang dimilikinya. Oleh karena itu besaran PDRB yang dihasilkan oleh masing-masing daerah sangat bergantung kepada potensi sumber daya alam dan faktor produksi Daerah tersebut. Adanya keterbatasan dalam penyediaan faktorfaktor tersebut menyebabkan besaran PDRB bervariasi antar daerah. 


\section{PDRB BERDASARKAN PENGELUARAN}

Kuncoro (2001) menyatakan bahwa pendekatan pembangunan tradisional lebih dimaknai sebagai pembangunan yang lebih memfokuskan pada peningkatan PDRB suatu provinsi, kabupaten, atau kota. Sedangkan pertumbuhan ekonomi dapat dilihat dari pertumbuhan angka PDRB. Saat ini umumnya PDRB baru dihitung berdasarkan dua pendekatan, yaitu dari sisi sektoral/lapangan usaha dan dari sisi penggunaan. Selanjutnya PDRB juga dihitung berdasarkan harga berlaku dan harga konstan. Total PDRB menunjukkan jumlah seluruh nilai tambah yang dihasilkan oleh penduduk dalam periode tertentu (BPS. Kab. Subang, 2018). Berikut disajikan data tentang PDRB menurut pengeluaran wilayah Kabupaten Subang.

Tabel 1. PDRB atas dasar harga Berlaku Menurut Pengeluaran, Kabupaten Subang 2013 - 2017

\begin{tabular}{|c|c|c|c|c|c|}
\hline \multicolumn{4}{|c|}{ Kabupaten Subang $2013-2017$} & Iiliar $\mathrm{Rp} /$ & illion $R p$ ) \\
\hline $\begin{array}{c}\text { Komponen } \\
\text { Pengeluaran/Expenditure } \\
\text { item }\end{array}$ & 2013 & 2014 & 2015 & 2016 & 2017 \\
\hline (1) & (2) & (3) & (4) & (5) & (6) \\
\hline $\begin{array}{l}\text { 1. Konsumsi Rumah } \\
\text { Tangga/Household } \\
\text { Consumption }\end{array}$ & 18420,62 & 20163,82 & 22194,39 & 24159,42 & 26088,67 \\
\hline $\begin{array}{l}\text { 2. Konsumsi LNPRT/NPISH } \\
\text { Consumption }\end{array}$ & 206,28 & 222,72 & 215,74 & 231,63 & 254,93 \\
\hline $\begin{array}{l}\text { 3. Konsumsi } \\
\text { Pemerintah/Government } \\
\text { Consumption }\end{array}$ & 1955,70 & 2141,82 & 2572,52 & 2754,08 & 2949,10 \\
\hline $\begin{array}{l}\text { 4. Pembentukan Modal Tetap } \\
\text { Bruto/Gross Fixed Capital } \\
\text { Formation }\end{array}$ & 6159,93 & 7394,45 & 8185,41 & 8839,51 & 9624,91 \\
\hline $\begin{array}{l}\text { 5. Perubahan } \\
\text { Inventori/Changes of } \\
\text { Inventory }\end{array}$ & 1228,29 & 1304,04 & 1269,27 & 1470,13 & 1527,25 \\
\hline PDRB / GRDP & 24732,54 & 26815,27 & 29307,92 & 31489,63 & 34167,00 \\
\hline
\end{tabular}

Sumber: BPS Kab. Subang 2018 
Grafik 1. PDRB atas dasar harga Berlaku Menurut Pengeluaran, Kabupaten Subang 2013 - 2017

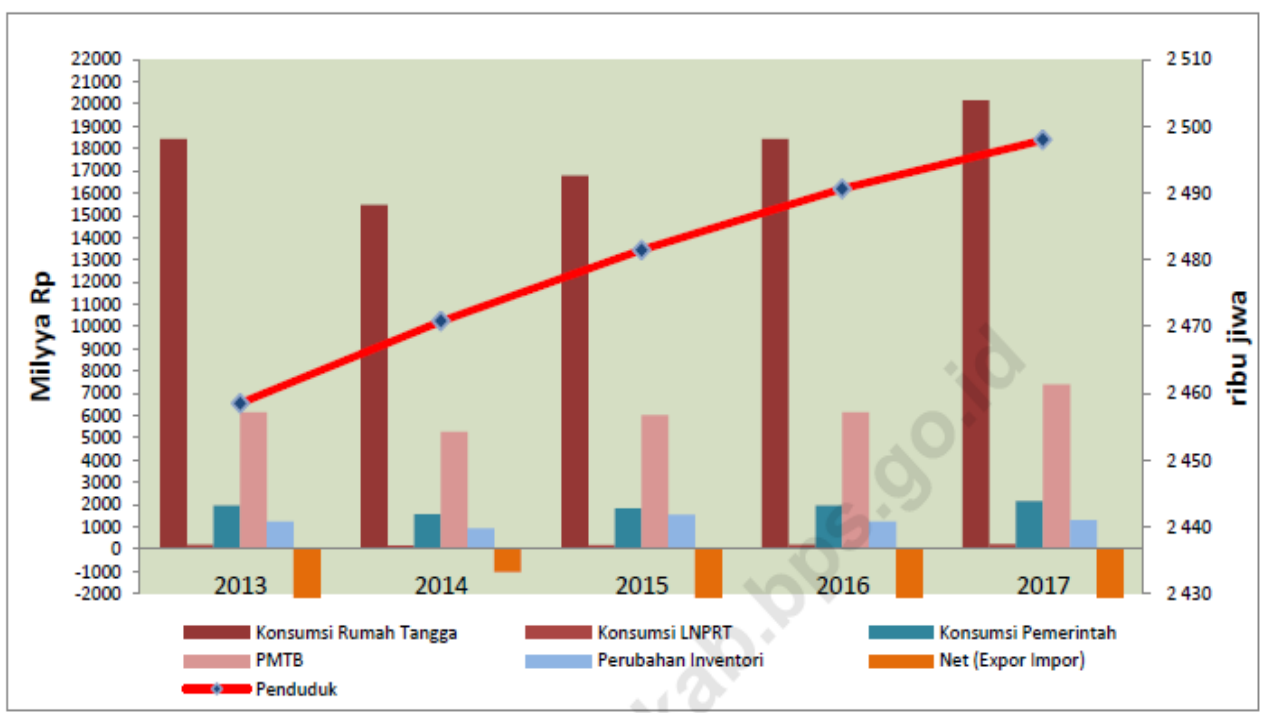

Sumber: BPS Kab. Subang 2018

Berdasarkan data dalam tabel dan grafik tersebut di atas, maka dapat dianalisis bahwa PDRB Kabupaten Subang atas dasar harga Berlaku di tahun 2017 meningkat sebesar 8,5\%, yakni dari 31.490 miliar Rupiah $(2000=100)$ menjadi 34.167 milliar Rupiah $(2010=$ 100). Jika dinilai atas dasar harga Konstan 2010, maka peningkatan yang terjadi lebih kecil, yakni dari 24.977 miliar Rupiah $(2000=100)$ menjadi 26.251 miliar Rupiah $(2010=100)$, atau meningkat sebesar 5,1\% (BPS. Kab. Subang, 2018). Namun walaupun demikian, data tersebut sudah menunjukan bahwa PDRB kabupaten subang mengalami peningkatan yang siginifikan untuk tahun 2017 (BPS. Kab. Subang (2018)

Dari hasil analisa data tersebut di atas, dapat disimpulkan bahwa walaupun kondisi pertumbuhan ekonomi Indonesia yang cenderung melemah, perekonomian Kabupaten Subang periode 2013 - 2017 dapat tetap tumbuh di atas 4\%, yakni sebesar 4,09\%; 5,02\%; $5,29 \% ; 5,40 \%$; dan 5,10\% (BPS. Kab. Subang, 2018). Peningkatan volume ekonomi tersebut tercermin baik dari sisi produksi (supply side) maupun sisi permintaan akhir (demand side). Dari sisi produksi, pertumbuhan ekonomi tertinggi terjadi pada kategori Informasi dan Komunikasi yang selalu tumbuh di atas $6 \%$ setiap tahunnya. Dari sisi permintaan akhir, pertumbuhan ekonomi Kabupaten Subang didominasi pertumbuhan komponen Pengeluaran Konsumsi Rumahtangga (PK-RT), yang menyumbang lebih dari separuh total PDRB.

Selanjutnya dapat kita lihat bahwa di periode tahun 2013 - 2017 PDRB Kabupaten Subang atas dasar harga berlaku, dapat dikatakan mengapami peningkatan yang cukup signifikan, yakni sebesar 24.732 miliar Rupiah (2013); 26.815 miliar Rupiah (2014); 29.308 miliar Rupiah (2015); 31.490 miliar Rupiah (2016); dan 34.167 miliar Rupiah. Peningkatan ini dipengaruhi baik oleh perubahan harga maupun perubahan volume. Peningkatan PDRB sisi produksi diikuti oleh peningkatan PDRB dari sisi permintaan akhir atau PDRB pengeluaran. (BPS. Kab. Subang, 2018)

\section{PDRB BERDASARKAN KOMPONEN PENGELUARAN KONSUMSI AKHIR RUMAHTANGGA (PK-RT)}

Komponen lain dari peningkatan PDRB sebagai ukuran pertumbuhan ekonomi yaitu Komponen Pengeluaran Konsumsi Akhir Rumahtangga (PK-RT) yang merupakan pengeluaran terbesar atas berbagai barang dan jasa yang tersedia. Data berikut 
menunjukkan bahwa dari seluruh nilai tambah bruto (PDRB) yang diciptakan di Kabupaten Subang, ternyata sebagian besar masih digunakan untuk memenuhi kebutuhan konsumsi rumahtangga. Dengan kata lain, sebagian besar produk (domestik) yang dihasilkan di wilayah Kabupaten Subang maupun produk (impor) yang didatangkan dari luar wilayah atau luar negeri akan digunakan untuk memenuhi kebutuhan konsumsi akhir oleh rumahtangga (BPS. Kab. Subang, 2018). Selanjutnya dapat dilihat berdasarkan data pada tabel berikut:

Tabel 7. Perkembangan Komponen Konsumsi Rumahtangga

Kabupaten Subang 2013-2017

\begin{tabular}{|c|c|c|c|c|c|}
\hline Urai a n & 2013 & 2014 & 2015 & 2016 & 2017 \\
\hline (1) & (2) & (3) & (4) & (5) & (6) \\
\hline Konsumsi $\quad$ Rumah & & & & & \\
\hline otal of Household & & & & & \\
\hline $\begin{array}{l}\text { a. ADHB / Currrent Prices (Miliar } \\
\text { Rp/Trillion Rp) }\end{array}$ & 18420,62 & 20163,82 & 22194,39 & 24159,42 & 26088,67 \\
\hline $\begin{array}{l}\text { b. ADHK 2010/2010 Constant Prices } \\
\text { (Miliar Rp/Trillion Rp) }\end{array}$ & 15890,69 & 16517,49 & 17163,93 & 17976,75 & 18809,45 \\
\hline $\begin{array}{l}\text { Proporsi terhadap PDRB/ Proportion } \\
\text { to GRDP } \\
\text { ( } \% \text { ADHB / Currrent Prices) }\end{array}$ & 74,48 & 75,20 & 75,73 & 76,72 & 76,36 \\
\hline \multicolumn{6}{|l|}{$\begin{array}{l}\text { Kata-rata konstums per- } \\
\text { Kapita/ Average of per-capita } \\
\text { consumtion (Ribu Rp/Thousand Rp) }\end{array}$} \\
\hline $\begin{array}{l}\text { a. ADHB / Currrent Prices (Miliar } \\
\text { Rp/Trillion Rp) }\end{array}$ & 12305,96 & 13326,23 & 14511,94 & 15627,05 & 16696,65 \\
\hline $\begin{array}{l}\text { b. ADHK 2010/2010 Constant Prices } \\
\text { (Miliar Rp/Trillion Rp) }\end{array}$ & 10615,83 & 10916,37 & 11222,74 & 11627,91 & 12037,98 \\
\hline \multicolumn{6}{|l|}{ Pertumbuhan/Growth ${ }^{7}$} \\
\hline $\begin{array}{l}\text { c. Total konsumsi RT/ Total of } \\
\text { Household Consumption }\end{array}$ & 3,27 & 3,94 & 3,91 & 4,74 & 4,63 \\
\hline d. Perkapita/Per capita & 2,16 & 2,83 & 2,81 & 361 & ccess 3,53 \\
\hline $\begin{array}{l}\text { Jumlah penduduk/Number of } \\
\text { population ( } 000 \text { orang/person) }\end{array}$ & 1496,89 & 1513,09 & 1529,39 & 1546,00 & 1562,51 \\
\hline
\end{tabular}

Sumber: BPS Kab. Subang 2018

Berdasarkan data di atas, dapat disimpulkan bahwa, secara rata-rata konsumsi per rumahtangga dari tahun ke tahun mengalami kenaikan, baik menurut atas dasar harga berlaku maupun atas dasar harga konstan 2010. Pada tahun 2013, setiap rumahtangga di Kabupaten Subang menghabiskan dana sekitar 42.670 ribu Rupiah setahun untuk memenuhi kebutuhan konsumsinya. Pengeluaran tersebut meningkat/menurun menjadi 46.208 ribu Rupiah (2014); 50.708 ribu Rupiah (2015); 54.604 ribu Rupiah (2016); dan 58.342 ribu Rupiah (2017). Sementara itu, atas dasar harga Konstan (2010) rata-rata konsumsi per rumahtangga tumbuh pada kisaran 4,1\%, dengan pertumbuhan tertinggi terjadi pada tahun 2016 sebesar $4,74 \%$ (BPS. Kab. Subang 2018)

Secara umum pada komponen konsumsi rumah tangga kabupaten mengalami pertumbuhan yang cukup siginifikan yaitu mencapai $4,74 \%$ di tahun 2016, ini menandakan bahwa kebutuhan perumahtangga masyarakat kabupaten subang cukup tinggi. Hal ini terjadi karena faktor pertumbuhan ekonomi secara umum di kabupaten subang dan peningkatan sifat konsuntif masyarakat kabupaten subang yang cukup tinggi. Sehingga menyebabkan peningkatan konsumsi rumahtangga masyarakat kabupaten subang secara umum di rentang tahun 2013 sampai 2017. 
Oikos: Jurnal Kajian Pendidikan Ekonomi dan IImu Ekonomi, ISSN Online: 2549-2284

Volume III Nomor 1, Februari 2019

\section{PDRB BERDASARKAN LAPANGAN USAHA}

Nilai PDRB Kabupaten Subang dari tahun 2010-2015 masih didominasi oleh Pertanian, Perternakan dan Kehutanan, Perdaganagan, Hotel dan Restoran. Sektor tersebut dari tahun ke tahun mempunyai peran yang paling besar dalam pembentukan PDRB Kabupaten Subang (Predisetian, 2017). Untuk lebih jelasnya dapat dilihat pada tabel berikut ini.

\section{Tabel PDRB Kabupaten Subang Tahun 2010-2014 Atas Harga Konstan Tahun Dasar 2010 Menurut Lapangan Usaha} ( dalam juta Rupiah )

\begin{tabular}{|c|c|c|c|c|c|c|c|c|c|c|c|}
\hline \multirow{2}{*}{$\begin{array}{l}\text { Se } \\
\text { kt } \\
\text { or }\end{array}$} & \multicolumn{2}{|l|}{2010} & \multicolumn{2}{|l|}{2011} & \multicolumn{2}{|c|}{2012} & \multicolumn{2}{|l|}{2013} & \multicolumn{2}{|c|}{2014} & \multirow{2}{*}{$\begin{array}{r}2015 \\
\text { PDRB }\end{array}$} \\
\hline & PDRB & $\%$ & PDRB & $\%$ & PDRB & $\%$ & PDRB & $\%$ & PDRB & $\%$ & \\
\hline 1 & $2.175 .005,12$ & 29,50 & $2.261 .781,2$ & 29,37 & $2.290 .944,7$ & 28,46 & $2.327 .251,8$ & 28,04 & $2.642 .621,9$ & 29,89 & $2.732 .631,2$ \\
\hline 2 & $835.831,84$ & 11,34 & $835.223,24$ & 10,85 & $894.398,95$ & 11,11 & $891.638,63$ & 10,74 & $989.364,67$ & 11,19 & $997.872,53$ \\
\hline 3 & $1.066 .473,26$ & 14,46 & $1.132 .047,8$ & 14,70 & $1.229 .517,2$ & 15,27 & $1.311 .526,0$ & 15,80 & $1.356 .741,2$ & 15,34 & $1.431 .731,4$ \\
\hline 4 & $83.766,25$ & 1,14 & $87.882,16$ & 1,14 & $90.156,22$ & 1,12 & $101.431,44$ & 1,22 & $121.226,35$ & 1,37 & $152.291,35$ \\
\hline 5 & $205.679,40$ & 2,79 & $219.314,02$ & 2,85 & $224.533,09$ & 2,79 & $233.806,93$ & 2,82 & $254.481,65$ & 2,87 & $275.671,39$ \\
\hline 6 & $1.722 .860,48$ & 23,37 & $1.825 .075,7$ & 23,70 & $1.923 .507,0$ & 23,90 & $1.983 .899,4$ & 23,90 & $1.997 .556,2$ & 22,59 & $2.222 .421,4$ \\
\hline 7 & $375.498,58$ & 5,09 & $393.413,33$ & 5,11 & $405.366,06$ & 5,04 & $417.349,32$ & 5,03 & $434.521,54$ & 4,91 & $476.632,72$ \\
\hline 8 & $310.952,20$ & 4,22 & $329.120,80$ & 4,27 & $344.200,34$ & 4,28 & $356.143,88$ & 4,29 & $361.224,22$ & 4,08 & $391.281,67$ \\
\hline 9 & $597.144,25$ & 8,10 & $617.159,08$ & 8,01 & $646.820,44$ & 8,04 & $676.322,01$ & 8,15 & $683.223,56$ & 7,72 & $698.467,92$ \\
\hline $\begin{array}{c}\text { To } \\
\text { t. }\end{array}$ & $7.373 .211,38$ & 100 & $7.701 .017,5$ & 100 & $8.049 .444,1$ & 100 & $8.299 .369,5$ & 100 & $8.840 .961,3$ & 100 & $9.370 .001,7$ \\
\hline
\end{tabular}

Sumber: BPS Kab. Subang dalam Predisetian (2017)

Keterangan: 1. Pertanian, 2. Pertambangan dan Pengalian, 3. Industri pengolahan, 4. Listrik, gas dan air bersih, 5. Bangunan, 6. Perdagangan, hotel dan restoran, 7. Pengangkutan dan komuniksai, 8. Keungan, jasa perusahaan, 9. Jasa-jasa

Selanjutnya data dari tabel di atas dapat digambarkan dalam bentuk grafik berikut ini.

Grafik PDRB Kabupaten Subang Tahun 2010-2014 Atas

Harga Konstan Tahun Dasar 2010 Menurut Lapangan

Usaha

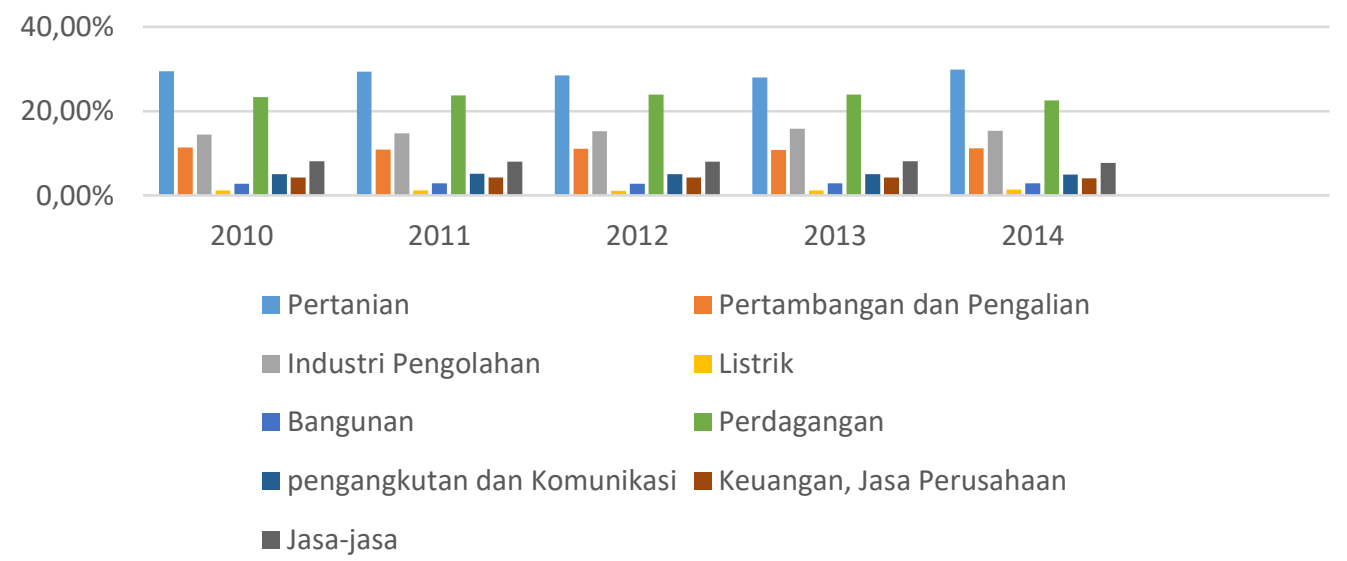

Sumber: BPS. Kab. Subang dalam Predisetian (2017)

Dari tabel dan grafik di atas dapat disimpulkan bahwa PDRB sektor 1 (Pertanian, Perternakan, Kehutanan) di Kabupaten Subang dari tahun 2010 sampai tahun 2014 
mempunyai sumbangan paling tinggi diantara sektor lainya dan mempunyai kecenderungan yang semakin meningkat nilai PDRB disetiap tahunya. Pada tahun 2010 nilai sektor 1 (Pertanian, Kehutanan, Perternakan) yaitu 2.175.005,12 pada tahun 2010, pada sektor 1 sumbangan 29,50\%, dan 2.290.944,79 pada tahun 2012 dengan sumbangan $28,46 \%$, serta 2.732.631,26 pada tahun 2015 dengan sumbangan $29,89 \%$ pada sektor 1 . Kemudian nilai paling tinggi/unggul selanjutnya berada di sektor 6 (Perdagangan, Hotel dan Restoran) berada diposisi kedua dengan nilai PDRB sebesar 1.722.860,48 pada tahun 2010 dengan sumbangan $23,37 \%$ pada sektor 6 , dan 1.923.507,07 pada tahun 2012 dengan sumbangan 23,90\%, serta 2.193.556,21 pada tahun 2014 dengan nilai sumbangan 22,59\%. Sedangkan sektor 3 (Industri Pengelolaan) di posisi ketiga dari sembilan sektor PDRB, pada tahun 2010 yaitu $1.066 .473,26$ dengan nilai sumbangan $14,46 \%$, dan $1.229 .517,21$ pada tahun 2012 , serta 1.356.741,21 pada tahun 2014 dengan nilai sumbangan 15,34\% pada sektor 3 (Predisetian, 2017).

Pejelasan di atas tentunya akan sangat bermanfaat untuk menganalisa bagaimana peluang usaha, atau kesempatan kerja ke pada masyarakat Kab. Subang. Kesempatan kerja adalah banyaknya orang atau tenaga kerja yang dapat terserap untuk bekerja pada suatu perusahaan atau suatu instansi, kesempatan kerja ini akan menyerap semua tenaga kerja yang tersedia apabila lapangan pekerjaan yang tersedia mencukupi atau seimbang dengan banyaknya tenaga kerja yang tersedia. (Disnakernas, 2000). Dengan adanya ketersediaan lapangan kerja yang memadai tentu akan mempercepat proses pembangunan ekonomi apalagi disertai dengan produktivitas yang tinggi. Suatu peluang untuk mendapatkan pekerjaan diberbagai sektor ekonomi disebut dengan kesempatan kerja.

Pembangunan ekonomi daerah adalah suatu proses dimana pemerintah daerah dan masyarakat menegelola sumber daya yang ada melalui suatu pola kemitraan untuk menciptakan lapangan kerja atau kesempatan kerja baru dan merangsang pertumbuhan ekonomi (Arsyad 1999). Menurut Jhingan (2004) pertumbuhan ekonomi yang pesat mendorong penyediaan berbagai sarana dan prasarana perekonomian yang dibutuhkan untuk mempercetpat pembangunan ekonomi. Indikator pembangunan ekonomi suatu negara terletak pada pertumbuhan ekonomi dan kesempatan kerja, sumber daya manusia merupakan faktor terpenting dalam pertumbuhan ekonomi.

\section{PENUTUP}

Pertumbuhan ekonomi tidak semata-mata tergantung pada sumber daya manusia saja, tetapi lebih menekankan pada efisiensi mereka. Bagaimana tata sistem pengelolaan dan pemanfaatan potensi sumber daya manusia dalam menunjang pertumbuhan ekonomi daerahnya.

Analisis PDRB pengeluaran terfokus pada perilaku penggunaan barang dan jasa akhir, baik untuk tujuan konsumsi akhir, investasi (fisik), maupun perdagangan luar daerah. Empat kelompok sektor atau pelaku ekonomi yang menggunakan barang dan jasa akhir dalam suatu perekonomian adalah rumah tangga, lembaga non-profit yang melayani rumah tangga/LNPRT, pemerintah, dan perusahaan.

Di tengah kondisi pertumbuhan ekonomi Indonesia yang cenderung melemah, perekonomian Kabupaten Subang periode 2013 - 2018 dapat tetap tumbuh di atas 4\%. Dari sisi produksi, pertumbuhan ekonomi tertinggi terjadi pada kategori Informasi dan Komunikasi yang selalu tumbuh di atas 6\% setiap tahunnya. Dari sisi permintaan akhir, pertumbuhan ekonomi Kabupaten Subang didominasi pertumbuhan komponen Pengeluaran Konsumsi Rumahtangga (PK-RT), yang menyumbang lebih dari separuh total PDRB kabupaten subang. 
Oikos: Jurnal Kajian Pendidikan Ekonomi dan IImu Ekonomi, ISSN Online: 2549-2284

Volume III Nomor 1, Februari 2019

\section{DAFTAR PUSTAKA}

Anitasari, M., \& Soleh, A. (2012a). Pengaruh Pengeluaran Pemerintah Terhadap Pertumbuhan Ekonomi Di Provinsi Bengkulu. Ekombis Review, 1(1), 117-127.

Badan Pusat Statistik 2010-2014 Kabupaten Subang

Badan Pusat Statistik. (2018). Produk Domestik Regional Bruto Kabupaten Subang Menurut Pengeluaran 2013-2017. Subang

https://id.wikipedia.org/wiki/Pertumbuhan_ekonomi. Diakses pada Minggu, 6 Januari. 2019

Lincolin Arsyad .(1999). Shift Share Analysis .BPFE UGM: Yogyakarta

Micheal Todaro. (2000). Pembangunan Ekonomi Dunia Ketiga. Penerbit Erlangga Jakarta

Predisetian, Aan (2017). Analisis Potensi Ekonomi Daerah Kabupaten Subang Tahun 20102015. Perpustakaan Fakultas Ekonomi dan Bisnis Unpas Bandung.

Putra, \& Windhu. (2017). Dampak Pengeluaran Pemerintah Terhadap Pertumbuhan Ekonomi dan Indeks Pembangunan Manusia di Perbatasan Indonesia. Jurnal Ekonomi Bisnis Dan Kewirausahaan, 6 (2), 120-138. 